\title{
A SHRED OF EVIDENCE ON THEORIES OF WAGE STICKINESS*
}

\author{
Alan S. Blinder and Don H. ChOI
}

A small interview survey was undertaken to see how actual wage-setters would react to the central ideas of several economic theories of wage stickiness. Wage cuts were surprisingly prevalent in recent years, despite the booming economy. The strongest finding was that managers believe that perceptions of fairness play a major motivational role in labor markets and that a "fair" wage policy is a good deal more complicated than simply not cutting wages. We also found substantial evidence for money illusion and against the adverse-selection version of the efficiency wage model.

Why are wages sticky, especially in the downward direction? Does the stickiness apply to nominal, real, or relative wages? Although these questions are central to at least some macroeconomic theories, satisfactory answers have eluded economists for decades-though not for lack of theoretical effort. Almost a decade ago, Arthur Okun [1981, p. 9] opined that "the Keynesian wage floor has been subjected to more Talmudic exegesis than any other passage in the history of economics." In the intervening years the theoretical literature on wage rigidity has exploded. By now economists have more theories than they know what to do with.

Empirical research is supposed to discriminate among competing theories; and econometric evidence may eventually eliminate some theories from contention. Currently, though, it seems to us that new theories are sprouting up faster than old ones are being rejected. Part of the problem is that many theories of wage rigidity rely on unobservable variables and hence are difficult to reject with the kinds of data that econometricians usually have. With this problem in mind, we turn in this study to an unconventional type of data, the sort that economists (alone among social scientists) rarely use: we actually asked a small sample of wage-setters about the nature and sources of wage rigidity in their own companies. ${ }^{1}$

*We are grateful to Orley Ashenfelter, Costas Azariadis, Laurence Ball, Allan Drazen, Alan Krueger, David Romer, Carl Shapiro, Andrei Shleifer, Lawrence Summers, Richard Thaler, Andrew Weiss, and two anonymous referees for helpful comments. And we are especially grateful to the managers who participated in the survey.

1. Blanchflower and Oswald [1987] report on a large British survey of personnel managers. Its focus was quite different from ours, however. Our study is closest in spirit to Kaufman [1984].

( 1990 by the President and Fellows of Harvard College and the Massachusetts Institute of Technology.

The Quarterly Journal of Economics, November 1990 
The paper begin with a brief description of the survey design. Then we summarize the results that bear on several modern economic theories of sticky wages. As will be seen, the adverseselection model receives rather little support from the survey results, while models based on costly labor turnover receive more support. Finally, we report survey results on noneconomic theories of sticky wages based on the elusive concept of "fairness." It appears that concern for fairness may have more to do with wage stickiness than do conventional economic factors such as risk sharing, shirking, and adverse selection.

We hasten to add that the evidence we offer here, based as it is on only a small sample, is far from decisive. Nor does it preempt future econometric work on wage rigidity, which should and will continue. However, in view of both the difficulty of using econometrics to discriminate among competing theories of wage rigidity and the paucity of survey data on the subject, we think that even the shred of evidence we offer here is worth having.

\section{The INTERVIEWS}

In March 1988 one of us interviewed either the manager of compensation or the personnel director of 19 firms in New Jersey and eastern Pennsylvania. ${ }^{2}$ Given the small scale of the study, a stratified random sample of New Jersey industry was out of the question. Instead, the sample was selected from Ward's Business Directory of U.S. Firms, which lists companies with annual sales over $\$ 11$ million, with two purposes in mind: (a) to approximate the industrial composition of manufacturing in New Jersey (about 18 percent of employment in the state) and (b) to include some service firms (another 62 percent of employment) of interest (e.g., a large insurance company, a telephone company, and a small airline).

In total, 37 companies were approached; of these, 19 agreed to participate. Our final sample consisted of 13 manufacturing companies ranging in size from 60 to 4,000 employees and six service companies ranging in size from 150 to 80,000 employees. The median number of employees was 450 , but the mean was 5,767 , reflecting the inclusion of three very large companies. Unionization rates ranged from zero (in six of the companies) to 90 percent; the median was 40 percent, and the (weighted) mean was 33 percent.

2. The interviews were conducted by Choi as part of his senior thesis at Princeton University, which accounts for the geographic concentration. 
Although a fixed outline of questions (see the Appendix) was used in all interviews, the interviews themselves tended to be free-formlasting as little as 40 minutes or as long as two hours, depending on how much or how little the respondent chose to elaborate.

One surprising fact that was turned up is that money wage cuts are more common than we had imagined. Even though our interviews came at a time and place of extremely tight labor markets (unemployment rates were below 4 percent in many localities), a sizeable minority of firms had actually reduced wages to at least some employees in the recent past. Specifically, five of the 19 firms (26 percent) had recently cut money wages; while four others (21 percent) had reduced fringe benefits, mostly in minor ways. (Some details on the cuts are given below.) Unless our small sample is unrepresentative in some important respect, money wage cuts are more prevalent than many economists (including ourselves) have supposed. ${ }^{3}$ It could well be that this wage flexibility is a product of the 1980s and that less would have been found in a survey in 1978; we have no way of knowing that.

\section{Findings on Economic Theories of Sticky Wages}

One well-known theory of wage rigidity holds that less riskaverse firms sell insurance to more risk-averse workers by stabilizing the real wage in the face of fluctuations in the demand for labor. ${ }^{4}$ Managers were introduced to this theory by the following question:

QUESTION: One theory on why wages do not fall states that workers do not like unpredictable changes in income. Therefore, workers and employers negotiate a stable wage that does not tend to fall during recessions or rise during booms. This steady wage acts as a type of wage insurance for the worker. How plausible or relevant does this seem as one reason why wages do not fall?

Although the answers took many forms, ten of the 19 managers (53 percent) indicated that they found the idea somewhat "plausible or relevant." Thus, the implicit contract theory bottle is either half empty or half full, depending on your predisposition.

3. Real wages are even more flexible. Twelve of the 19 firms had reduced real wages in the recent past by raising money wages less than inflation. [1974].

4. The theory originated with Azariadis [1975], Baily [1974], and Gordon

5. For present and future reference, it is worth noting that the standard error of such a percentage in a sample of 19 ranges from about 11 percent (when the true probability is 50 percent) to about 7 percent (when the true probability is either 90 percent or 10 percent). 
There was much greater consensus on the importance of relative wages, a point made forcefully by Keynes [1936] and recently reemphasized by several writers. ${ }^{6}$ Firms were confronted with the following question:

QUESTION: One theory on why wages do not fall states that workers are concerned with how their wages compare to those of other types of workers. Workers want to maintain a hierarchy of wages for different types of workers, and resist wage reductions because, unless they are across the board, they will destroy traditional wage differentials. How plausible or relevant does this seem as a reason why wages do not fall?

Sixteen of the 19 managers (84 percent) responded that relative wages are important deterrents to wage reductions. Their answers were evocative of concern over relative wages, not over what the wages will buy. Several respondents offered such remarks as "money is status" or "we keep score according to how much people make" or that wage cuts are "ego demeaning."

Responses like that point strongly toward a noneconomic explanation of wage rigidity, and we shall examine this idea further in the next section. But they do not rule out conventional economic explanations, for, as Summers [1988] points out, most versions of efficiency-wage theory assign a central role to relative wages as well. We therefore inquired about three different efficiency-wage models: adverse selection, shirking, and labor turnover.

The adverse-selection model is based on three premises: (1) that workers differ in productivity; (2) that at least some of these productivity differences are unobservable; and (3) that unobservable productivity differences are correlated with alternative wages. If all three premises are true, then lowering the offered wage will attract an inferior applicant pool. ${ }^{7}$ Almost all firms (17 of 19 , or 89 percent) agreed that there are productivity differences among workers. However, apparently none of them would interpret a worker's rejection of a wage offer as evidence that his productivity is unobservably high. Specifically, managers were asked the following question:

QUESTION: There are two workers who are being considered for the same job. As far as you can tell, based on interviews, experience, education, and so forth, both workers are equally well qualified. One of the workers agrees to work for the wage you offer him. The other one says he needs more money to work for you. Based on this

6. See Blinder [1988], Summers [1988], and Akerlof and Yellen [1988].

7. See Weiss [1980], among others. 
difference, do you think one of these workers is likely to be an inherently more productive worker?

Not one of the 18 managers who responded to this question answered in the affirmative. We view this as damaging evidence against the adverse-selection model, a model that we had viewed as plausible on a priori grounds, unless there is a strong asymmetry (so that higher wages attract a superior applicant pool) or adverse selection applies only to quits, not to new hires.

Another version of efficiency-wage theory is based on moral hazard; one form this may take is shirking. Every firm believed that workers sometimes shirk on the job, which suggests that the theory holds promise. However, few thought that a higher wage would motivate greater work effort. When asked, "What are the most important factors in making an employee work hard?", only two of the 18 respondents ( 11 percent) mentioned wages while three others (17 percent) explicitly denigrated the importance of wages. Nonetheless, when asked a more pointed question-"If you lower wages, do you believe that employees will work less hard?"-13 of 19 (68 percent) managers answered yes, and two others said that workers would quit. These seemingly contradictory responses suggest either that responses to wage increases and decreases are asymmetric or, as will be seen below, that the response to a wage reduction depends on the reason for the cut.

The version of the shirking model that has received the most attention is due to Shapiro and Stiglitz [1984]. It holds that there is less shirking when unemployment is higher because the penalty for being caught and fired is greater; similarly, when wages fall, the threat of unemployment becomes less severe, and hence shirking rises. Every one of the 13 managers who said that a wage cut would lead to more shirking pointed to reduced morale, not to a decreased penalty for job loss, as the reason. However, when asked directly whether higher unemployment would lead to higher work effort among their workers, 13 of 18 respondents (72 percent) answered that it would. Depending on your predilections, these results can be read as either good or bad news for the Shapiro-Stiglitz model.

According to the labor turnover model, and to a considerable body of empirical evidence, ${ }^{8}$ lower wages lead to higher costs from increased turnover. Of the five firms that had reduced wages in the

8. See Pencavel [1970] or Krueger and Summers [1988]. 
recent past, only one reported a significant increase in labor turnover. Yet, when confronted with the hypothetical question, "If your firm reduced wages, do you believe the number of people who quit will increase?", all 18 respondents answered affirmatively. Once again, however, the reason for the wage cut seemed to matter. Six managers noted that the justification of the wage reduction was important to the turnover issue, while eight others mentioned the importance of wages paid by other firms. Finally, when asked specifically whether the costs of hiring and training new workers was one reason not to reduce wages, 11 of 16 respondents (69 percent) said yes. All in all, the survey results seem to support the idea that fear of labor turnover may deter wage reductions.

\section{FAIRnESS AND WAGE STICKINESS}

As we noted earlier, several firms said that whether or not a wage cut would reduce work effort or raise quit rates depends on how the wage cut is justified to workers. Generally, wage reductions made to save the firm from failure or to align wages with those of competitors are viewed as justifiable and fair while those made just to raise profits are not. ${ }^{9}$ In this light, it is interesting to see the circumstances under which money wages were cut in the five firms that did so. One large manufacturing company, facing declining demand and paying above-market wages, eliminated incentives and a cost-of-living clause. Two other manufacturers, also suffering from slack demand, cut wages temporarily and restored them when business improved. One manufacturer reclassified some workers into a lower job category, thereby reducing wages. The one service company that reduced wages did so for a group of workers that was being paid above the industry standard. ${ }^{10}$

Several questions were specifically addressed to the issue of "fairness." Two hypothetical situations were posed.

In the first, the local unemployment rate was posited to rise two percentage points at a time of zero inflation. Managers were asked whether they and their workers would perceive a wage reduction to

9. Of course, in a perfectly competitive market there is no distinction between wage cuts to avoid bankruptcy and wage cuts to raise profits. We doubt that this subtlety troubled our respondents. Blanchflower and Oswald [1987] also interpret their survey evidence as inconsistent with perfectly competitive markets.

10. Note, however, that our only evidence that the companies paying abovemarket wages were in fact doing so comes from the companies themselves. We have no way of knowing if they were just trying to rationalize wage cuts. 
take advantage of the labor market slack as (a) completely fair, (b) acceptable, (c) unfair, or (d) very unfair. Responding for themselves, three managers deemed the question irrelevant-the economist's answer, we suppose. Of the remaining 16, all but one (94 percent) said that such a wage cut would be unfair or very unfair. (The other one called it acceptable.) Answering on behalf of their workers, however, only one branded the fairness issue irrelevant; all the others said that their workers would consider such a wage cut unfair or very unfair.

The next hypothetical situation was identical except that both wages and prices were stated to be rising initially at 4.4 percent per annum. Managers were asked about the fairness of reducing the rate of wage increase. Results obtained by Kahneman et al. [1986] led us to suspect different answers, reflecting money illusion; and that is precisely what we found. Seven of the 15 managers who responded to this question (47 percent) said that reducing real wages by raising money wages less than inflation was fairer than cutting money wages when there is no inflation. More importantly, 10 of 17 respondents (59 percent) said their workers would find the real wage reduction through inflation less unfair than the money wage reduction. When queried about their different reactions to real versus money wage cuts, the usual explanation was not that people do not understand the concept of real wages, but rather that there is a psychological difference between taking away and not giving. Of course, to an economist, real wages are being "taken away" in either case.

Economists will want to know whether a reputation for being unfair is costly to a firm. So managers were specifically asked how a reputation for having an unfair wage policy would affect work effort, quits, and the quality of future applicants. The responses were clear and unequivocal. Sixteen of 19 (84 percent) said that turnover would rise; 18 of 19 (95 percent) said that work effort would fall; and all 19 said that the quality of future job applicants would suffer. Attitudes like this must be strong deterrents to implementing an "unfair" wage policy though, as we have seen, that does not necessarily rule out wage reductions under the right circumstances.

Thus, we reach three conclusions. First, the notion of fairness is important to the labor market, and there is at least some agreement among workers and managers about what is fair and what is not. Second, the common notion of fairness includes a money illusion, which is what Kahneman et al. found in another context. Third, 
firms believe that a reputation for being unfair will cost them dearly on the bottom line, as Okun [1981] suggested.

\section{CONCLUSION}

The opinions of managers of 19 firms in a geographically concentrated area hardly constitute the last word on anything. Yet we believe it is better evidence than introspection by academic theorists. And at least a few of the results turned up in this survey are so strong and so uniform that they tempt one to generalize-or at least to call for further research, including both survey evidence and econometric testing.

Principal among these is the idea, promoted by Okun [1981] and Akerlof [1982], that perceptions of fairness play a major motivational role in labor markets. Furthermore, commonly held notions of what constitutes a "fair" wage policy are more complicated than merely paying high wages or not cutting wages. They seem, for example, to include an important element of money illusion and even to allow money wage cuts under the right circumstances. The survey results also cast strong doubt on the empirical validity of the adverse-selection model while supporting the importance of labor turnover costs as a factor accounting for wage rigidity. Results on the risk-sharing and shirking models were less definitive.

\section{APPENDIX: The INTERVIEW OUTLINE}

\section{General Employment and Wages}

1. In one sentence or two, could you describe the products (services) your firm provides?

2. How many employees does your firm currently have?

For the sake of brevity, in this study the word "wage" will represent the total compensation to workers, so it includes money wages plus other benefits such as pensions and insurance.

3. a. Could you describe how your wages have changed over the past five years?

b. What were the reasons for these changes?

4. a. How does your firm determine the new wage and salary for a worker when it comes time to make adjustments?

b. How does your firm determine the wage or salary to offer a new employee? 
5. a. Do you have a set salary structure that provides certain wage levels for certain job positions?

b. If so, why do you have this structure?

6. Do your wage agreements with workers include specific standards of performance, such as piece quotas or other requirements? 7. a. In the recent past, has your firm ever laid off workers or reduced the workweek?

b. If so, what were the circumstances?

8. a. In the recent past, has your firm ever reduced wages?

b. If so, was it the money wage, the other benefits, or both, that were reduced?

c. If one was reduced but not the other, why did you choose to reduce that component?

d. What were the circumstances leading to the wage reduction? 9. During times of inflation, have there been times when wages in your firm have risen by less than the inflation rate?

10. a. Right now, could you find capable workers - that is, workers with similar qualifications and experience to your own-at less than current wages?

b. In recent history, have you been able to find capable workers at less than the wages you were paying?

c. If you have been able to find such workers, did you hire them?

\section{Monitoring}

1. Is it possible to monitor accurately the average work effort of a group of workers?

2. Compared to a group of workers, is it easier, harder, or equally possible to monitor the work effort of an individual employee?

3. If monitoring is possible, can it be done in an objective way verifiable by employees or a third party?

4. Does the possibility of monitoring depend on the type of worker involved, for instance, skilled vs. nonskilled?

5. If it is possible to monitor either group or individual work effort, do you do so?

\section{Legislation}

1. a. Are any of your workers currently receiving minimum wage, and if so, how many?

b. If the government were to raise the minimum wage to a point where you would have to raise the wages of your lowest paid 
employees, would this have any affect on the wages of employees receiving above minimum wage?

2. If unemployment benefit programs were increased, would the wages offered by your firm change?

\section{Unions}

1. a. What percentage of your employees are unionized?

b. For other firms in your industry, about what percentage of workers are unionized?

2. a. In your firm, how important are unions in preventing wages from falling for your union workers? In other words, if there were no unions, would your wages be any more likely to fall?

b. In your firm, how important are unions in preventing the wages of your non-union employees from falling? In other words, if there were no unions, would your wages be more likely to fall?

\section{Implicit Contracts}

One theory on why wages do not fall states that workers do not like unpredictable changes in income. Therefore, workers and employers negotiate a stable wage that does not tend to fall during recessions or rise during booms. This steady wage acts as a type of wage insurance for the worker. How plausible or relevant does this seem as one reason why wages do not fall?

\section{Relative Wages}

One theory on why wages do not fall states that workers are concerned with how their wages compare to those of other types of workers. Workers want to maintain a hierarchy of wages for different types of workers, and resist wage reductions because, unless they are across the board, they will destroy traditional wage differentials. How plausible or relevant does this seem as a reason why wages do not fall?

\section{Shirking}

1. What are ths most important factors in making an employee work hard?

2. a. Do you believe that some of your workers shirk on the job-that, in other words, they don't work as hard as they should?

b. Do you think this tendency is more prevalent among certain types of workers, or is it universal?

c. If a worker is repeatedly caught shirking, what are the penalties?

3. If unemployment were to rise, what do you think would happen to the work effort of your employees? 
4. a. If you lower wages, do you think employees will work less hard?

b. If so, why is this so?

5. a. Does the number of employees working together in a group affect the average work effort of the individuals in the group?

b. If there is an effect, what are the reasons behind it?

\section{Adverse Selection}

1. a. For a given job, are there productivity differences among workers?

b. Are these productivity differences accompanied by wage differences?

2. a. Do job applicants ever offer to work for less than the going rate?

b. If they do, do you hire them?

c. If you do not hire them, what are the reasons?

3. Before a worker starts on the job, how accurately can you predict his/her productivity?

4. Have you had applicants turn down job offers because they thought the wage or salary was too low?

5. There are two workers who are being considered for the same job. As far as you can tell, based on interviews, experience, education, and so forth, both workers are equally qualified. One of the workers agrees to work for the wage you offer him. The other one says he needs more money to work for you. Based on this difference, do you think one of these workers is likely to be an inherently more productive worker?

\section{Turnover}

1. What are the most common reasons why workers separate from your firm?

2. a. If your firm has, in the recent past, reduced wages, were there employees who quit because of this?

b. If so, why did lowering wages cause them to quit?

3. a. Have there been workers who have chosen to quit because they felt they were being paid too little?

b. If so, have there been more skilled or nonskilled employees who have quit for this reason?

4. a. If your firm reduced wages, do you believe that the number of people who quit would increase?

b. How important would the costs of rehiring and training new employees be as one reason not to reduce wages? 


\section{Conceptions of Fairness}

1. Let's say that unemployment in your area rises by 2 percent. One possibility is that you could reduce wages to take advantage of a larger labor supply. For this question, assume that there is no inflation.

a. Do you perceive this as: completely fair, acceptable, unfair, or very unfair?

b. Do you think your workers would perceive this as: completely fair, acceptable, unfair, or very unfair?

c. Do you think the general public would perceive this as: completely fair, acceptable, unfair, or very unfair?

d. If there are differences between your perception of fairness and other peoples' conception of fairness, what are the reasons for the differences?

2. The actual inflation rate is currently 4.4 percent, and let's assume that your employees are receiving yearly wage increases of 4.4 percent to keep up with inflation. If unemployment rises by 2 percent, one possibility is that you could reduce the wage increase to take advantage of a larger labor pool.

a. Do you perceive this as: completely fair, acceptable, unfair, or very unfair?

b. Do you think your workers would perceive this as: completely fair, acceptable, unfair, or very unfair?

c. Do you think the general public would perceive this as: completely fair, acceptable, unfair, or very unfair?

d. If there are differences between your perception of fairness and other peoples' conception of fairness, what are the reasons for the differences?

3. If your wage policy is generally considered to be unfair, how will this affect:

a. the behavior of your customers?

b. the work effort of your current workers?

c. the number of workers who quit?

d. the quality of your future job applicants?

Department of Economics, Princeton University

SCHOOL OF ARCHITECTURE, RICE UNIVERSITY

\section{REFERENCES}

Akerlof, George, "Labor Contracts as Partial Gift Exchange," Quarterly Journal of Economics, LXXXVII (November 1982), 543-69. , and Janet L. Yellen, "Fairness and Unemployment," American Economic Review, LXXVIII (May 1988), 44-49. 
Azariadis, Costas, "Implicit Contracts and Underemployment Equilibria," Journal of Political Economy, LXXXIII (1975), 1183-1202.

Baily, Martin N. "Wages and Employment under Uncertain Demand," Review of Economic Studies, XXXXI (1974,), 37-50.

Blanchflower, David G., and Andrew J. Oswald, "Internal and External Influences Upon Pay Settlements: New Survey Evidence," Centre for Labour Economics, Discussion Paper No. 275, London School of Economics, March 1987.

Blinder, Alan S., "The Challenge of High Unemployment," American Economic Review, LXXVIII (May 1988), 1-15.

Gordon, Donald F., "A Neo-Classical Theory of Keynesian Unemployment," Economic Inquiry, XII (1974), 431-59.

Kahneman, Daniel, Jack L. Knetsch, and Richard Thaler, "Fairness as a Constraint on Profit Seeking: Entitlements in the Market," American Economic Review, LXXVI (September 1986), 728-41.

Kaufman, Roger T., "On Wage Stickiness in Britain's Competitive Sector," British Journal of Industrial Relations, XXII (March 1984), 101-12.

Keynes, John Maynard, The General Theory of Employment, Interest and Money (1936).

Krueger, Alan, and Lawrence Summers, "Efficiency Wages and the Inter-Industry Wage Structure," Econometrica, LVI (March 1988), 259-93.

Okun, Arthur, Prices and Quantities: A Macroeconomic Analysis (Washington, DC: The Brookings Institution, 1981).

Pencavel, John H., An Analysis of the Quit Rate in American Manufacturing Industry, Industrial Relations Section (Princeton, NJ: Princeton University, 1970).

Shapiro, Carl, and Joseph E. Stiglitz, "Equilibrium Unemployment as a Worker Discipline Device," American Economic Review, LXXIV (June 1984), 433-44.

Summers, Lawrence H., "Relative Wages, Efficiency Wages, and Keynesian Unemployment," American Economic Review, LXXVIII (May 1988), 383-88.

Ward's Business Directory of Largest U. S. Companies, Vol. 1 (Belmont, CA: Information Access Company, 1987).

Weiss, Andrew, "Job Queues and Layoffs in Labor Markets with Flexible Wages," Journal of Political Economy, LXXXVIII (June 1980), 526-538. 